\title{
PLACE [SPACE] NON-PLACE
}

\author{
A B S T R A C T
}

Even if they never materialize as buildings, architectural projects belong to the real world. Immaterial but real, detached from the actual presence but not devoid of the measurable spatial properties, these sets of technical scale-drawings, descriptions and calculations explain the future physical reality in terms of space, materiality and form, aiming at a world at least slightly better than the one they originate from. A topographically challenging, splendid location by the sea; a specific, dense urban arrangement; an intriguing mindset: the immediate context precedes and follows the actual construction of an architectural piece. This is a self- evident fact that historicist conceptualizations and classifications cannot deny. UTOPIAN or REALIST, architectural projects by their virtue are bound to places. It is only the measure of their interference with these places that varies. In our post-globalized world, both the utopian and the realist qualities are to be found in projects hyperrealist to the immediate context and in those which address it only minimally, in mere terms of load distribution, adaptation to the actual topography, or climatic protection. 


\section{INTRODUCTION}

This text is a space-time collage featuring some real architectural projects set up against the background of the utopian, theoretical discourse on architecture. It is based on the lecture of the same name, with reflections on some other lectures delivered at the Architecture Utopia Realism conference. Written from the perspective of a practicing architect with some academic ambition and experience, it concentrates around a number of "key words" listed above; fundamental but mythical topics in fact, surrounding both the daily low-end practice and the high-end academic discourse on ARCHITECTURE. The discussion about the limits of the PROJECT and how an architectural project materializes into the physical reality refers also to the social position of the ARCHITECT, primarily to the scope of capabilities and responsibilities of our profession. How we process the MATERIAL found in the immediate CONTEXT, and how our projects may relate to the topics of PLACE and NONPLACE, is illustrated here with two competition entries from my architectural practice. The SPACE, however, remains the most abstract, therefore in brackets, central member of the above "key words" equation. Its actual materialization into a physical fact depends on an array of factors, but primarily on the ways we see, understand and draw the physical world that surrounds us.

\section{THE REALIST UTOPIA}

Lopud in the southernmost region of Croatia is the middle island of the Elaphitic Archipelago, at a distance of only seven miles from the north harbour of Dubrovnik and a single nautical mile from the mainland. The small town of the same name, stretched along the sandy bay protected from the unfavourable winds, experienced its biggest growth during the sixteenth century. Since the foundations for the island's economic development was the maritime trade, the recession in the Mediterranean which was to follow, led to the quick fall of the frail island economy. Up to the 1920s, the scarce population confined in some kind of time capsule, pursued extensive agriculture and fishing. The economic restoration was incited by the growth of a new service-related activity: tourism. Grand Hotel, designed and built in reinforced concrete by the young architect Nikola Dobrović (1897, Pécs - 1967, Belgrade), opened in 1937. Not coincidentally, that same year Piet Mondrian stated:

"The culture of particular form is approaching its end; the culture of determined relations has begun" 
For the purpose of construction, a quarry was established on the island and a small concrete factory was built. The crushed rock material was transported from the stone pit to the construction site in small wagons on the tracks installed along the quay. The construction with new materials and advanced technology represented an unseen attraction. The proportion of the impact of the new technology is splendidly illustrated by an (unauthenticated) quote, saying that one of the construction workers, originating from the nearby Pelješac peninsula, substituted reinforced cages for traditional wooden beds for oyster breading, thus improving the age old traditions. When the hotel opened, new jobs were offered and a "sustainable" development potential fitting the local community's capacity was secured for several future decades. The private enterprise thus secured the prosperity and continuity of the local community in the economic, social, institutional, even ecological sense. That is why this hotel might be seen as the paradigm of developmental and social sustainability, derived from the local community in almost all aspects: the REALIST UTOPIA. The only import from the great and distant, technologically advanced world was the architect. Himself on a professional travel, he saw the natural capital clearly, and made everything but the windows narrow and small, as all the foyers, the restaurants and the rooms were facing the sea. Staging the iconic sights of the times: voyage $=$ a ship-like building, exotics $=$ tall palm trees in the park, hedonism $=$ tennis court on the flat roof, Nikola Dobrović has changed the sleepy island life forever (Fig. 1).

But the world went different way, the designed, "sustainable" development never took place, and contradictions of the accelerated time of modernisation have linked the Grand Hotel to a series of tragic happenings which followed briefly after the hotel opening. During the Second World War, the hotel served

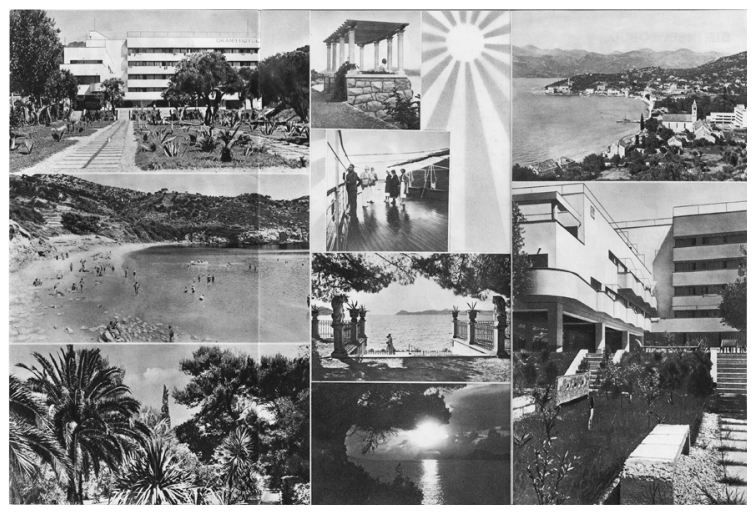

Figure 1. CONTEXT: Nikola Dobrović, Grand Hotel, Lopud near Dubrovnik (1937): a touristic leaflet from the period showing modern architecture in relation to the basic phenomena attracting the tourists to the remote island. Design by Gorjup, printed at Mariborska tiskarna, around 1937. 
as a place of internment of the Jews arrested in Dubrovnik and the neighbouring $\operatorname{areas}^{2}$, on a short station of their tragic journey. Immediately after the war, the hotel was nationalized following the change of the social paradigm. In the late 1970s it was thoroughly restored, without much interference in its original structure, except that the ventilation chimneys were inserted in the middle of the roof terrace: who would play tennis on the hot roof any longer? After the 1990s, the hotel was neglected due to the ownership issues, a consequence of another change of the social paradigm. In the process of (re)privatization, the Municipality of Dubrovnik exercised the right of pre-emption of the registered cultural monument and resold the hotel to a supposedly suitable owner, who was believed not to destroy, in the restoration process, this fine testimony to the short-lived, modernist belief in progress.

The turbulent history which started shortly after its completion only emphasized the utopian quality of this great work of modern architecture. In front of the hotel, the dynamic spatial composition was paired with the realization of public interest. Why has the hotel building been drawn back from the quay deep into the plot? To stage "the culture of determined relations" perceived in motion, as "the culture of particular form" was believed to have ended. We testify to that every time upon sailing into the Lopud harbour, or when we approach the hotel over the commander bridge displaced in parallel from the axis of the axially composed park, while observing a series of open park niches with reinforced concrete furniture lining up at the sides of the promenade. Now abandoned, Nikola Dobrović's venture into modern architecture is a splendid illustration of modern architect's noble intentions of being useful to the public, even when confined by the need to serve the private interests. The democratic concrete bench in front of the hotel, accessible to everyone, is this realist utopia's tiny surviving fragment (Fig. 2).

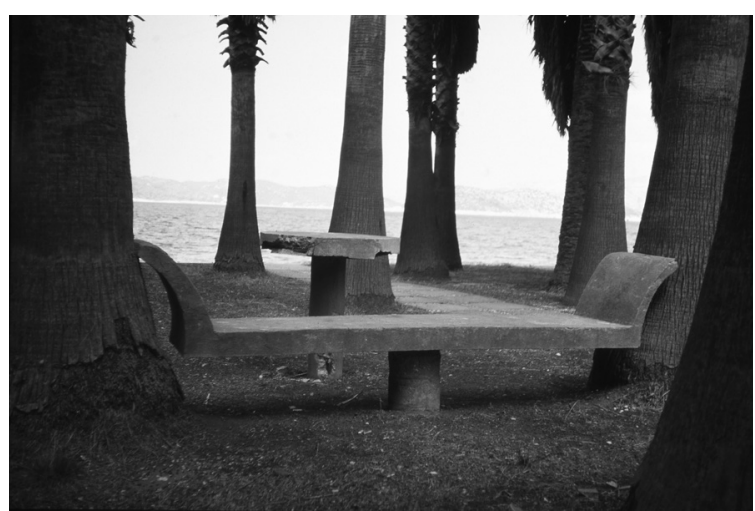

Figure 2. THE REALIST UTOPIA: the concrete bench in front of the Grand Hotel, photo by KI, 1998. 


\section{ARCHITECT(S) AND PROJECT(S)}

Two contextual perspective drawings of the Grand Hotel were published already in 1932, accompanying the programmatic text entitled "Contemporary Architecture by Southern Slavs" and significantly subtitled "Nikola Dobrović and his Significance"s. Written by the municipal conservator of Dubrovnik, it was published in the then only Yugoslav architectural magazine "Arhitektura". The author, Kosta Strajnić, who was already well known as the author of the first monographs on the architect Jože Plečnik and the sculptor Ivan Meštrović, canonized the young architect only in his early thirties as the most promising personality of the Yugoslav architectural scene. After the studies and the remarkable professional practice in Prague, and the sequence of successes at architectural competitions in the newly established Kingdom of Yugoslavia, Nikola Dobrović was to permanently settle in Dubrovnik around 1933. In less than a decade to follow, he managed to construct a series of houses-machines there, all of which we easily and undoubtedly recognize today as works of the heroic period of modern architecture. Yet, there is a specific value to his Dubrovnik opus: for Kosta Strajnić his architecture was "the most contemporary in the best sense of the word" "while Theo van Doesburg described his distinctive "artistic language" as "regionally derived". From a sufficient temporal distance, we recognize this specific value firstly in the imbuement of his architecture with universal humanist ideas and rational principles - Dobrović named them the "confluents of thought" to architecture ${ }^{6}$ - not only within modern architecture's main international trajectory nor as its somewhat exotic Mediterranean offspring, but also in the context of general, non-conceptual and timeless architectural concerns of form, structure, materiality, space and place. In architect's own words, written shortly before the end of his life:

"Spatial art stands high above all other art forms. Any architect or architecture enthusiast can easily believe this. "

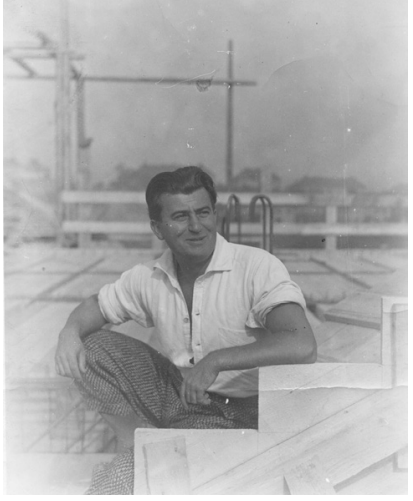

Figure 3. THE PRAGMATIC ARCHITECT: Nikola Dobrović photographed on the Grand Hotel construction site, around 1937. Courtesy Belgrade Museum of Science and Technology, Architecture Department.

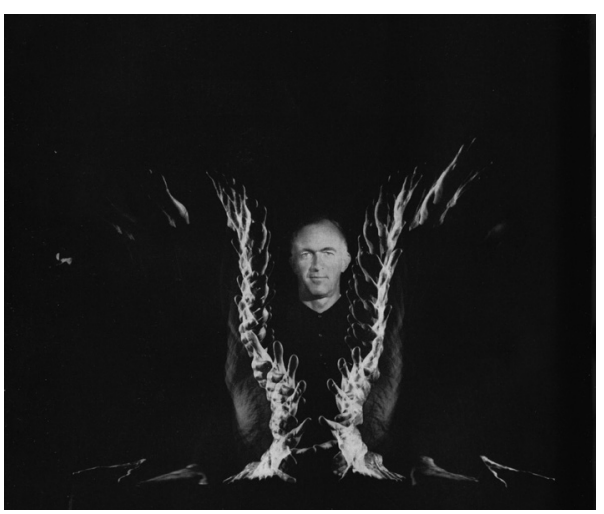

Figure 4. THE IDEALIZED ARCHITECT: Jørn Utzon explaining the seagull's wing principle he wanted to apply in construction of the glass walls of the Sydney Opera House. Photographer Joseph Vissel took thirty exposures of his hands on the same negative for the illustration of Sigfried Giedion's milestone article "Jørn Utzon and the Third Generation" published in Zodiac 14, 1965. 
Looking at the photograph of the young, PRAGMATIC ARCHITECT in control of everything, at the beginning of his fruitful career, who has a diploma from a respectable technical university, who knows about structure and about materials, and who gets his hands dirty at the construction site, makes one believe this sounding statement (Fig. 3). Like in Immanuel Kant's formalist system, architecture appears greater not only than painting and sculpture. Dobrović makes us believe that architecture can also be regarded as greater than nature.

Significance of the Sydney Opera House for architectural history was recognized before the building has beens completed. Approximately one third of Zodiac no 14 of 1965 was dedicated to its author Jørn Utzon (1918, Copenhagen - 2008, Copenhagen), and more than one half out of this third to the Opera House project. A decade after the competition was launched and less than a year prior to the architect's resignation from the construction site, Utzon, at the time in his late forties, was canonized as the one who was opening the way to the "third generation" of modern architecture (Fig. 4). Sigfried Giedion's milestone article Jørn Utzon and the Third Generation ${ }^{9}$ was announced as a new chapter of the fifth edition of his Space, Time and Architecture. Among the "sensitive characteristics" of the third generation "sharply delineated" in Utzon, Giedion has pointed out the distinctive "attitude to the past", fascination by the "unity of primitive structures", placing of the "horizontal plane in the foreground as a constituent element of their architecture" and close relation to the contemporary (abstract) sculpture. He also gave a brief overview of the Sidney Opera competition course, describing how the jury member Eero Saarinen "recognized the world significance of Utzon's entry" and pressed the jury to award the project that had initially been eliminated from the competition. Giedion claimed the architect was going "beyond the purely functional... in order to enhance the force of expression" here; something so clearly manifested in the Sydney Opera project (Fig. 5). But some other aspects of this article relate Utzon's masterpiece more directly to our time:

Firstly, while advocating the "independence of expression from function", Giedion also warned that "only a master hand can dare to manifest it... in the hands of minor talents this can only lead to sliding off the rails." Secondly, as we can read between the lines, Giedion was actually advocating the actual project faced with "a remarkable amount of opposition". Difficulties in its completion were to unfold very soon. The process that had begun by Utzon's "elation beyond comparison" 10 when the competition results were announced in January 1957 was abrupt by his resignation from the construction site in February 28, 1966 with a letter to the regional Minister of Public Works. Costs 
of construction have been overrun, the newly elected government has been ignoring architect's fee claims for some time already, but Utzon's “... as I see clearly that you do not respect me as the architect" "11 indicates a more important fact: at this point the position of architects in the hierarchy of responsibilities has substantially changed. Minister Davis Huges' infamous organisational diagram which Utzon did not want to accept shows how architects have slide down the food chain: from the "project" to "design", now subsided to new members in the equation (Fig. 6). In the Sydney Opera case, to "architects panel" and "government architect"; in a more general contemporary situation, to "project managers" and an array of so called "consultants". The Government's position was opportunistically backed up by the Royal Institute of Australian Architects and the leading structures and the Builders' Labourers' Federation. On Utzon's side, independent architects, intellectuals, students and professors of architecture from the Sydney University, musicians from the Sydney Symphony Orchestra and even construction workers gathered in the public protest with no equal in history of architecture. The Utzon-in-Charge; later Bring-Utzon-Back movement has spanned over a couple of years, gaining great public support on local and international levels. Luis Kahn was famously quoted that "the sun didn't know how beautiful its light was until it was reflected from this building" ${ }^{\prime 2}$, but the battle was lost. The date of Utzon's withdrawal is the day the idea about the PROJECTS as something technically and culturally unambiguously belonging to patrons and to the ARCHITECTS, started to collapse.

The disappointed architect left Australia with his family and never returned. The construction costs for the Opera have doubled after his departure, which did not trouble the management to open it without the presence of the IDEALIZED ARCHITECT portrayed in Zodiac 14 while performing the space-time miracle with thirty exposures of his hands.

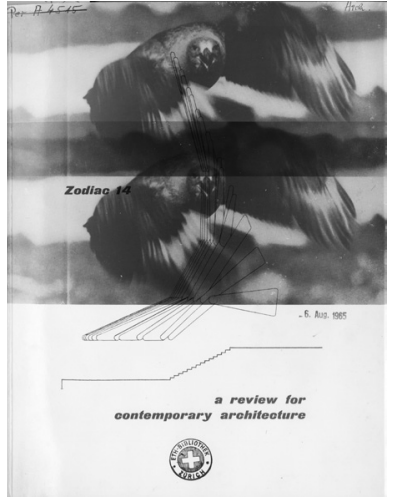

Figure 5. Cover page of Zodiac 14,1965 , featuring the space-time comparison of the Sidney Opera mullions and the seagull's flight.

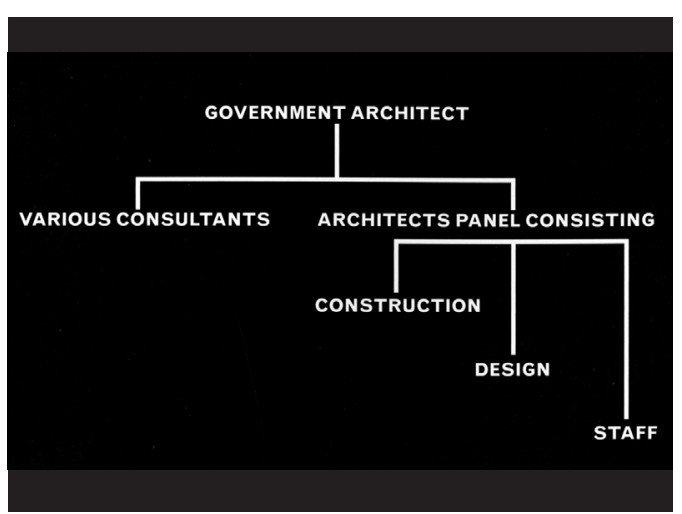

Figure 6. "DESIGN" INSTEAD OF THE PROJECT: The infamous Minister of Public Works' diagram of responsibilities Utzon rejected on February 28, 1966. Architect's scope is limited under "design"; the project is dissolved and new members appear on the scene. 
THE PLACE: MAGNIFIERS OF NATURAL

AND TECHNOLOGICAL ELEMENTS, 2009

From his journey back home to Denmark via Mexico, Jørn Utzon wrote to his Australian colleague Bill Wheatland:

"Went to Yucatan. The ruins are wonderful. So why worry? Sydney Opera House becomes a ruin some day. "13

Those lines recall his famous article Platforms and Plateaus ${ }^{14}$ published in Zodiac no 10 of 1962, while the Sidney Opera was in the last phase of construction. He wrote about the constructed mountain with truncated top there: the giant platform in Yucatan, raised amidst the dark jungle, only to put a temple on its sunlit top. By raising the platform exactly in the height of the top of the jungle that surrounded it, a spatial condition was created that radically opposed the given natural conditions: "Suddenly the jungle roof had been converted into a greater open plain" and Mayans were given the sensation of the horizon. Before the platform was built, they could have no idea about it. Pediments to architecture, the platforms are similar to the great infrastructural objects. They are indeed greater than their surroundings and yet the physical shape of the surroundings is their most important reference.

When Erwin Rommel asked Curzio Malaparte whether he had bought his house on Capri ready- made or he had designed it for himself, the writer allegedly replied that the house had been there and he designed the scenery. "Ach, so!" the general reportedly exclaimed ${ }^{15}$. This anecdote illustrates how the limits of architecture may be radically extended, and how an architectural object, regardless its physical size, may gather and explain a truly vast natural or urban site. The idea about architecture as greater than nature is at the very fundament of modern architecture. In Le Corbusier famous note from Le Voyage d'Orient:

"One collects the shell only for its pearl. The temples are the cause of this landscape." 16

"Poetic and pathetic at the same time"; this is how an Italian botanist $\mathrm{t}^{17}$ described the Montenegrin nature some hundred years ago. Mratinje area, where the washed-out, gigantic dam has become an integral part of the landscape is the best proof for such a reading, even though it has been hardly "natural" for already thirty-five years at least. The hydro power plant with the concrete arch dam the fifth biggest in the world of its kind and the accumulation lake of 880 million cubic metres was constructed in 1975. About 45 kilometres of the Piva River canyon were drowned under the accumulation. It took 732,94 $\mathrm{m} 3$ of concrete to build the dam, 220 metres high, its arch 286 metres long. Before the canyon was flooded and the hydro power plant fully operational, the 
sixteenth century monastery of great cultural significance had to be moved to a higher position. Together with the monastery, the precious frescos on its interior walls were moved too, including the image of a person in Turkish robes painted next to the southern entrance to the monastery. It is believed that it portrays the famous Mehmed Paša Sokolović, the grand vizier of three Ottoman sultans who probably provided finances and favourable conditions for construction of the monastery at this particular place.

It is certain that the scenery of the river gorge was astonishing also before the dam was erected in the most logical place, where the canyon narrowed at most. Driven by the pure engineering logic, big infrastructural works such as the walls of Dubrovnik or this dam usually benefit from the strategic positions they logically occupy. Still, natural and technological elements rarely blend so "natural" as they do here. With construction of the dam, the narrow gorge and steep cliffs have become only narrower and steeper, their natural properties technologically magnified. Occasionally, when it rains a lot and accumulation level is high, they are additionally adored with aerosol of the artificial waterfall. On the other side of the dam, an impressive liquid platform measures the natural course of elements magnifying their inhuman proportions. With weathering, the dam has become an integral part of nature; an entirely new and totally artificial "natural" rarity of Montenegro, perfectly nested in its scarce karst embossment. The sublime qualities of this place were the departure point for this project ${ }^{18}$.

The intervention is concentrated on the sunny end of the dam, in front of the concrete reinforcement of the cliff. Conceived in five phases it can work well at any stage of completion: the subsequent phases introduced five devices; the five magnifiers of "natural" and "technological" elements of this melancholic and heroic landscape (Fig. 7):

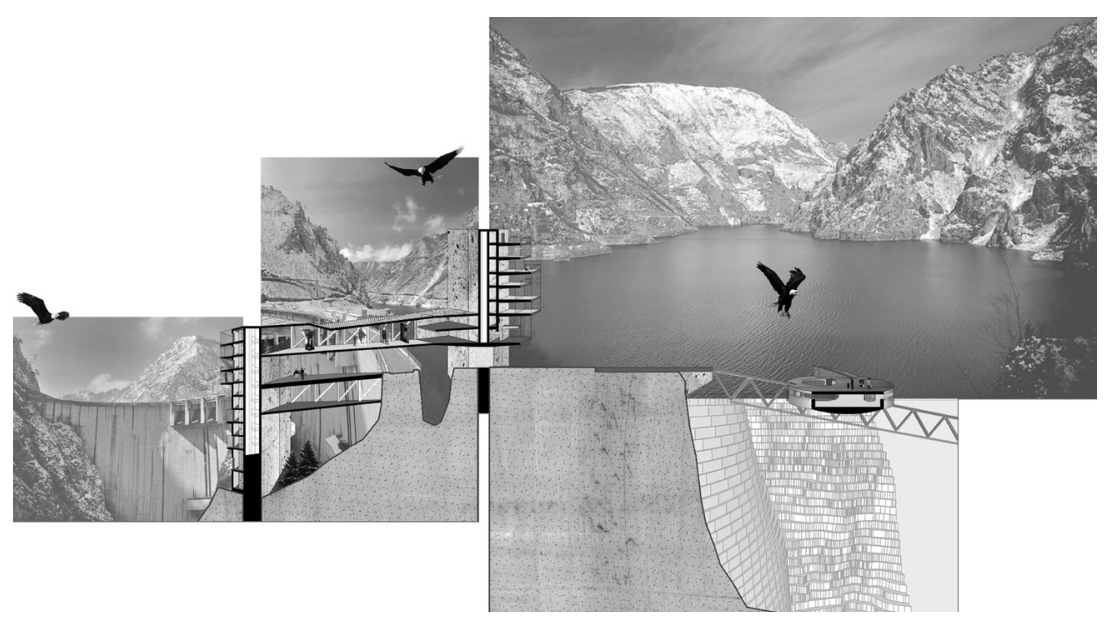

Figure 7. THE PLACE: IVANIŠIN. KABASHI. ARHITEKTI, Magnifiers of Natural and Technological Elements, project, 2009: five devices set in a space-time collage. CIVANIŠIN. KABASHI. ARHITEKTI 
I: Tower- Down protrudes from the cliff in front of the dam. II: Plateau at the level of the dam offers the distant view of the natural spectacle of the gorge in front and the close view of the occasional spectacle of the artificial waterfall. III: Tower- Up grows behind the dam touching the water accumulation at its highest level. IV: Bridge is suspended between the two towers, opening the total, panoramic view of the elements. V: Floating Platform offers the ultimate sublime experience. By the highest accumulation level, it sits by the shore. As the level of the artificial lake descends, it slides down the inclined beam which is also the access ramp, eventually to dock the opposite shore at the lowest accumulation level. Inside the platform is the half-sunken restaurant, offering the rare sensation of the view exactly at the level of the silent water mirror. Constantly changing its level in accordance with the natural cycle and the human intervention, it measures the endless iteration of time. This project presents a sequence of eventspaces tightly bound to the phenomena found on THE PLACE.

NON-PLACE : FRIDAY MOSQUE, 2013

Probably the most important consequence of the monotheism for our reasoning about the physical world around us is the understanding that everything in heavens and on earth has a purpose: "He it is who has made the sun a [source of] radiant light and the moon a light [reflected], and has determined for it phases so that you might know how to compute the years and to measure [time]..." (Qur'an, 10: 5). There is no mystery in the immanent world. It is not accidental, but dominated by reason. Natural facts that constitute it are meant to explain the intentions of the creator: "Do they not look at the sky above them how We have built it and made it beautiful and free of all faults? And the earth - We have spread it wide, and set upon it mountains firm, and caused it to bring forth plants of all beauteous kinds, thus offering an insight and a reminder unto every human being who willingly turns unto God. "(Qur'an, 50: 6-8) $)^{19}$

That contemporary natural sciences and philosophy owe to the development of abstract thinking- astronomy and mathematics in particular- during the first thousand years of Islam, is a commonplace. The $9^{\text {th }}$ century's practical application of this advancement in natural sciences onto the "sacred geography" aimed to determine the right direction of prayer from ANY PLACE associated with the regions of the known world with certain astronomical phenomena by means of special maps and mechanical devices such as compasses and astrolabes ${ }^{19}$ (Fig. 8). Within such spiritual but mechanically enhanced understanding of the world, the monotheistic idea about nature as non-conceptual and sublime appears strikingly similar to that of the rationalist, Cartesian- Newtonian natural science. The monotheism may indeed be seen as disenchantment and rationalization of 
all nature. Its authentic sacred places are no enchanted groves, holy springs, mysterious lakes or caves where mythical creatures and elemental spirits reside, but small number of special places where the earthy order was subject to the divine intervention through unusual cosmic and geological occurrences: Ka'ba was built at the location where a meteorite hit the ground in times of Adam and Eve, Moses was given the tablets with thunders and lightings in a thick cloud at the Mount of Sinai (Exodus 19), and Jesus yielded up the ghost with a sun eclipse (Luke 23) and an earthquake (Matthew 27) ${ }^{20}$ on Golgotha. Naturally, the monotheistic idea about natural world has consequences for human interventions in it. Islam suggested certain general principles by means of which the cosmic order should be revealed in architecture which, depending on the actual spatial and material conditions, govern architecture of prayer places in particular. Any clean space can serve that purpose:

"The whole world has been made a place of prayer, pure and clean" (Hadith Muslim) $^{21}$.

While the lunar calendar denies the natural seasonal cycle of the solar year, the times of daily prayers: between dawn and sunrise, just after the height of the midday sun, just after sunset... deliberately avoid the exact times delineated by the daily natural cycle because of their pagan connotations. The primary act of individual submission is paired with the physical experience, thus the cognitive rule of facing the universal omphalos for believers anywhere in the world, the Ka'ba in Mecca, can be explained as the ontological axis of prayer, the Qibla $^{22}$. The practice of Islam indeed requires orientation in space and time, but this orientation is referential to the order beyond the easily perceptible, natural one. Consequently, the non-interference with nature should be the ruling principle beyond architecture. The monotheistic faith can have no associated symbolic form, hence the reluctance of investing an edifice with any symbolic;

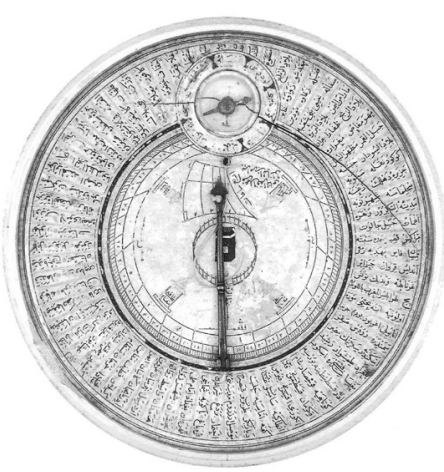

Figure 8. Qibla indicator and compass made by Bayram ibn Ilyas, 1582, diameter $11 \mathrm{~cm}$ : in the centre of the world is the Ka'ba, around the rim regions and cities of the Islamic world. "Sacred geography" developed in the ninth century onwards, to determine the direction of prayer from different regions of the world. (C) The Trustees of the British Museum world. CThe Trustees of the British Museum $(1921,0625.1)$

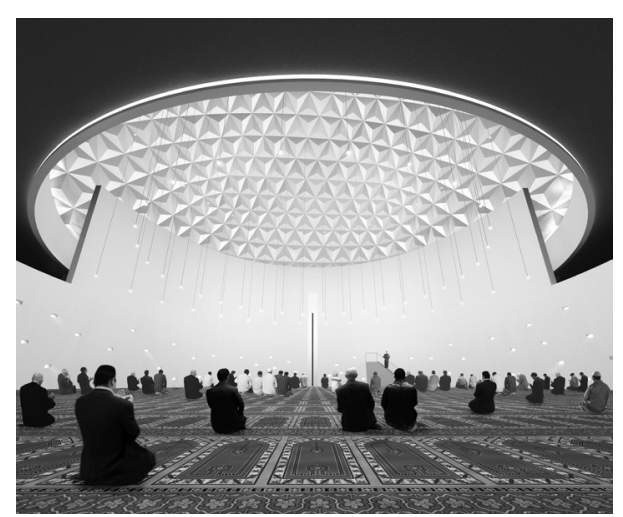

Figure 9. NON PLACE: IVANIŠIN. KABASHI. ARHITEKTI, Friday Mosque, project, 2013: the main prayer hall. CIVANIŠIN. KABASHI. ARHITEKTI 
representative connotation. A mosque represents nothing. It relates to the natural laws only in terms of the load distribution manifested in the bearing structure and of the minimal adaptation to the climate. It refers to the actual physical surroundings- urban, rural or natural, only in terms of the necessary adjustments to the actual topography.

Clear geometries and dominant horizontality govern the mayor historical (proto) types: the expanding structural pattern of La Mezquita in Cordoba and the giant or small hollowed mountains of the Ottoman tradition likewise. Like in Edmund Burke's definition of the sublime ${ }^{23}$, division, addition, rhythm, pattern and repetition deceive the senses. This is how the "field" plan of La Mezquita can endlessly grow ${ }^{24}$, and how a large dome and a chandelier suspended low over a field of colourful carpets can resemble the sky. Like in Immanuel Kant's definition of the sublime as non-referential to nature but to our reasoning about $\mathrm{it}^{25}$, in terms of space, volume and form- detached from the immediate surroundings- an ideal mosque relates to the supreme abstract order. The void, not the solid is its main immanent objective (Fig. 9).

Any mosque is the NON-PLACE; a paradigm of the non-conceptual architecture.

\section{THE POINT OF VIEW}

Ara Güler's photograph of the steep passage leading to the courtyard of the mosque Sinan the Architect made for the grand vizier Mehmet Paşa Sokolluthe same Mehmed Paša Sokolović painted by the Piva monastery entranceproves that the flatten perspective of the Ottoman miniature also characterizes the best works of the classic Ottoman architecture (Fig. 10). "Intelektualistische Vorstellung"'26; this is how, in the sketch book from his journey to the Orient, under the drawing of a ceramic tile from the Valide mosque in Istanbul depicting the Ka'ba, young Le Corbusier described this rational and analytic way of spatial representation of the world seen from above. The way of seeing, the way of drawing and the way of building are causally related. The essence of things is immutable but our physical environment is constantly changing. Consequently, as by drawing an analytic cross section or a transparent axonometric projection, when we think about our projects, we should not be interested in how things look like or what they stand for, but in what the things substantially are.

Le Corbusier (1887, Chaux-de-Fonds - 1965, Cap-Martin) was only in his early twenties when probably the most important journey in the history of modern architecture took place in 1911. Sinan (1489, Ağırnas - 1588, Istanbul) was already fifty in 1538, when he became the head of the Imperial Body of 
Architects, an institution in charge of practically everything related to the Empire's civil engineering, urban development and architecture. It functioned as an educational institution too, responsible also for construction of bridges, forts and other military structures in war times. Given the quantity of big and small mosques and other public buildings to be constructed by Sinan or under his control during the next fifty (!) years throughout the Ottoman territories, his attempt at the perfection of an architectural type ${ }^{27}$ must be seen as instrumental in a much larger attempt at the rationalization and at the architectural formalization of the vast expanding Empire. One of the aims beyond the construction of Süleymaniye was to match the greatness and the splendour of thousand years older Holy Wisdom. This is why a similar floor plan was chosen- allegedly upon the request of the client- and the site on the hill which was topographically closing the Golden Horn peninsula. The disposition of the buildings of the complex surrounding the mosque, the alternating heights of the four minarets... everything contributes to the sublime sensation of a sphere sitting on top of a hill; the artificial mountain dominating the skyline (Fig. 11). The interior is a vast, almost square room with plan indeed similar to that of Hagia Sophia but without the galleries and, because the columns are so high and so far apart, without the real barrier between the central area and the walls. The space is centralized and continuous ${ }^{28}$, calculated to perplex the imagination. It demonstrates the improvement of knowledge and wisdom and the domination of reason over our senses. In words of the humble "subject of Süleyman Han":

"In this building, all of the fine arts have been put to the service of this project in perfect harmony." 29

This "perfect harmony" may be found in proportional relations between the main elements of the overall composition, in the comparison of the base angles of the void pyramid contained within the vast interior space and the actual,

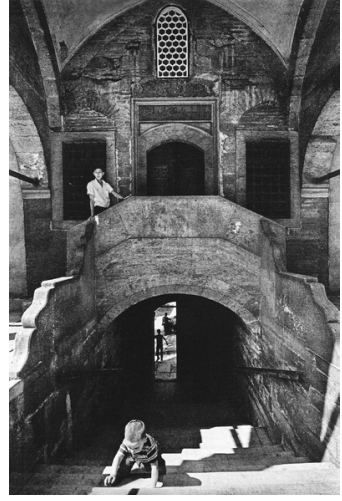

Figure 10. Ara Güler, Sokollu Mosque, Kadirga, 1988: the passageway under the school leading to the Sokollu Mehmet Paşa Mosque's courtyard (1572). (C)Ara Güler

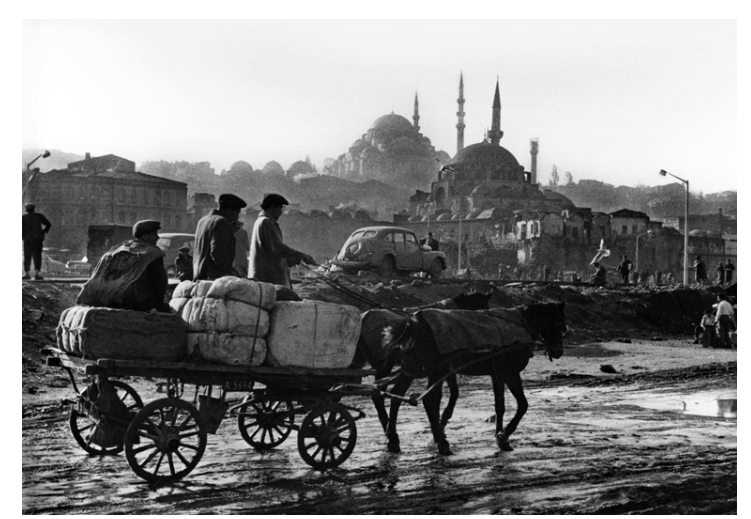

Figure 11. Ara Güler, Eminönü, 1960: two mosques built by Sinan: the Rustem Paşa Mosque(1562) elevated on a platform over the profane daily life is in the first plan; in the second plan is the Süleymaniye (1557), dominating the skyline. (C)Ara Güler 
solid pyramids of Giza: the number $\pi$, the earth's curve angle, the natural e logarithm, the Fibonacci sequence... one anonymous, ecstatic text found on the internet even states that the "measurements of the spaces within the mosque demonstrate that these spaces are the same as those using in the calligraphic writing of the word 'Allah", 30 .

\section{CONCLUSION: THE UNSTABLE BALANCE}

A sphere sitting on top of a hill: the unstable balance is an equilibrium state of a system in which any departure of the system from the equilibrium gives rise to tendencies moving the system further away from the equilibrium. This basic mechanics' paradigm may also apply to architecture:

From a remote perspective, a distinct setting of elements: a topographically challenging geographical location, a specific urban arrangement or a narrative mindset may be named CONTEXT: what precedes, what follows and what provides the material for the construction of an architectural piece. The giant AIR cruiser, nothing like a kinetic agent of some romanticist veduta- floats languidly. The intestine SPARKLE holds it in the AIR above the city deeply rooted into the same ROCK it was made of. The immense SEA surrounds the scene. Natural and artificial ELEMENTS in this collage are in the unstable balance. The gravitational force anchors architecture firmly to this unstable but certain, elemental world of Newtonian classical physics and natural philosophy (Fig. 12).

Elements with their distinct properties, in four substantial STATES OF MATTER, constitute the sets the architects work with and within: SOLID: earth, rock, mineral, is the container. It stands for firmness although natural forces and human interventions do challenge its durability. LIQUID: water, sea, and GAS: air, wind, climate, atmosphere are contained. They cycle, standing for cohesion and motion simultaneously. PLASMA: fire, spark, technology, is the opposite and the ultimate dissolution of solid. It stands for permanent change and metamorphosis. Solid, liquid, gas, plasma and their combinations provide material for architecture, materializing AETHER: spirit, idea, the disputed quintessence into a physical fact: the abstract SPACE brought down to earth. Its material existence becomes certain only when rectified into a coordinated set of drawings; an architectural PROJECT bound to the specific PLACE, presenting the exact, material, future state of things. Once constructed, as we know, it becomes more than just the air contained within the solid walls.

Unlike the other three classical elements, the fire-except the radiant sunlight and the reflected moonlight - was rarely seen in the unmediated natural wilderness. It was rather an exception coming either from the heaven (a lightning) or from 


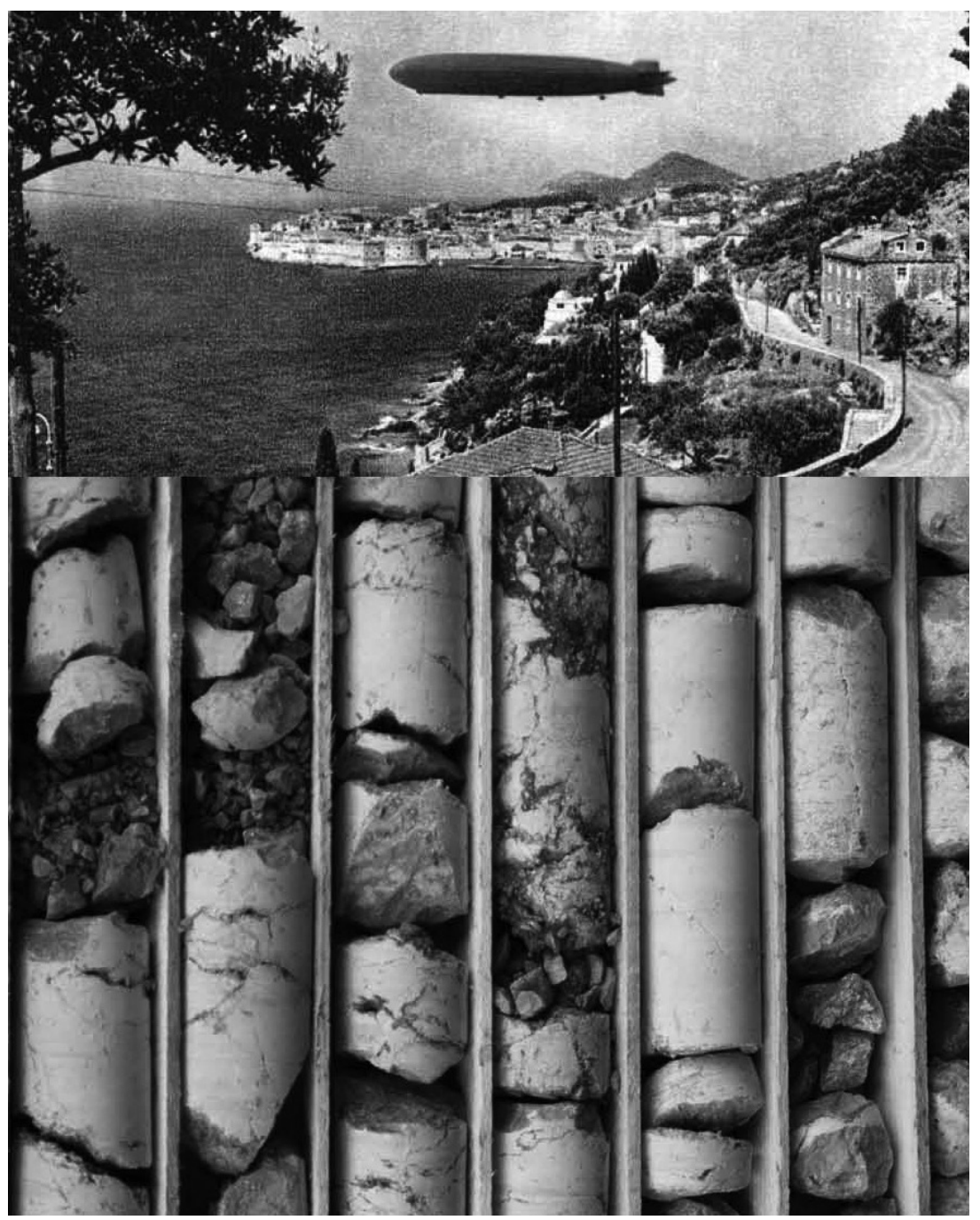

Figure 12. KI: The Unstable Balance II, digital collage, Dubrovnik, April 2012: the found photograph taken on March 27th 1929, of the Graf Zeppelin airship floating over Dubrovnik on the way back from Cairo to Friedrichshafen, set against the digital photograph taken by KI in 2004, of the karst bedrock samples from the construction pit for the parking garage in Dubrovnik, showing the limestone and the dolomites at the depth around $10 \mathrm{~m}$. OKrunoslav Ivanišin 
the underworld (a volcanic eruption). For Heraclitus, it was the principle behind everything in nature. Vitruvius (II:I) designed it as the origin of architecture: it was the heat of fire that brought people together to form the society and "having from nature this boon beyond other animals, that they should walk, not with the head down, but upright, and should look upon the magnificence of the world and of the stars", as " they also easily handled with their hands and fingers whatever they wished" ${ }^{\prime \prime} 1$, construct their first shelters out of the matter at their disposal. From the moment the flame was protected from the natural elements, THE HEARTH became the artificial core of architecture. In The Four Elements of Architecture, Gottfried Semper named it the first and the most important, moral element of architecture. The other three elements grouped around it: THE ROOF, THE ENCLOSURE and THE MOUND, are the "protective negations" of the natural elements: WATER, AIR and EARTH, aggressive to the artificial hearth FIRE $^{32}$. Hence the daring idea about architecture as greater than nature, the idea that an architectural object regardless its size and its exposure to erosion and decay, may measure, define and explain that nature.

Artificial as it is, architecture - just like a rock, a mountain or a tree - still grows towards the sun, the clouds, the sky, and the stars. But, again like that rock, that mountain and that tree, it also remains firmly bound to the ground: the AXIS MUNDI. We are born with this elemental consciousness: little children indeed look upon the magnificence of the world and their eyes point to the starry heaven, but when drawing people, they see only heads and eyes, with legs extended until the lower limit of the frame. As architecture has immanent, physical roots, we may paraphrase the famous Mies van der Rohe's "feet on the ground - head to the clouds" ${ }^{33}$ paradigm: both our feet are - moreover - in earth, and it is only fire that helps our head - occasionally - reach clouds. 
Sigfried Giedion, “ Jørn Utzon and the Third Generation,” Zodiac (Milano) 14 (1965): 36- 47. Jørn Utzon, Foreword to Building a Masterpiece: the Sydney Opera House, ed. Anne Watson (Sydney: Powerhouse, 2006), p. 7.

Anne Watson, "Bring Utzon Back: the Protest that Divided Profession," in Building a Masterpiece, ed. Anne Watson, p. 155.

Hanna Browny and Patricia Hale, “'A Masterpiece of Human Creative Genius': Recognition, Reconciliation and Heritage Conservation," in Building a Masterpiece, ed. Anne Watson, p. 170. Browny and Hale, p. 163.

Jørn Utzon, "Platforms and Plateaus,” Zodiac (Milano) 10 (1963): 110-115.

Stan Allen and Marc McQuade, eds., Landform Building (Baden: Lars Müller, 2011), pp. 33-37. Le Corbusier, Journey to the East (1911), trans. Ivan Žaknić (Cambridge Mass.: MIT Press, 2007).

Antonio Baldacci (1867- 1950) has done extensive research on the plant life in Montenegro, Albania and Greece around the turn of the centuries.

For the detailed description of the project, see Goran Radović (ed.), Places for Re-encouters: Recycling the Space (exhibition catalogue). La Biennale di Venezia, 2010, pp. 26-40.

Qur'an, english translation by Muhammad Asad (1980), in Asad, Muhamad. The Message of the Quran. Gibraltar: Dar Al Andalus, www.usc.edu/schools/college/crcc/private/cmje/religious text/ The Message of The Quran_by_Muhammad_Asad.pdf, accessed October 26, 2013. Abdel M.A.S. Haleem, “The Importance of Hajj: Spirit and Rituals; Sacred Geography," in Hajj, Journey to the Heart of Islam, ed. Venetia Porter (London: The British Museum Press, 2012), p. 66. Bible, King James Version, Cambridge edition, http://www.kingjamesbibleonline.org, accessed October 10, 2013.

Ruqaiyyah Waris Maqsood, Islam (London: Hodder \& Stoughton Educational, 2003), p. 113. Akel Kahera, Latif Abdulmalik and Craig Anz, Design Criteria for Mosques and Islamic Centres (London: Elsevier Architectural Press, 2009).

Edmund Burke, A Philosophical Inquiry into the Origin of Our Ideas of the Sublime and the Beautiful (1756), in The Works of the Right Honourable Edmund Burke, Volume the First (London: Jonn C. Nimmo, 1878). The Project Gutenberg EBook \#15043, released March 27, 2005.

Stan Allen, "Field Conditions", in Stan Allen Architects: Points + Lines (Princeton: Princeton Architectural Press, 1999), pp. 92-102.

Immanuel Kant, Critique of Judgement; Part I: Critique of Aesthetic Judgement (1790), trans. James Creed Meredit. eBooks (Adelaide, University of Adelaide), http://ebooks.adelaide.edu. $\underline{\mathrm{au} / \mathrm{k} / \mathrm{kant} / \mathrm{immanuel} / \mathrm{k} 16 \mathrm{j} / \mathrm{index} . \mathrm{html}}$.

Le Corbusier, in the sketchbook from his Journey to the East (1911): "Intellektuallistische Vorstellung" [Intellectual Representation], reproduced in Le Corbusier- the Art of Architecture (Basel: Vitra Design Stiftung, 2007), p. 172.

Ranko Radović, Antologija kuća [An Antology of Houses] (Belgrade: Građevinska knjiga, 1989), p. 68 .

John Freely, A History of Ottoman Architecture (Boston: WIT Press, 2011), p. 251.

Reha Günay, A Guide to the Works of Sinan the Architect in Istanbul (Istanbul: Yem Yayin, 2006), p. 94.

NA, "The Magnificent Suleymaniye Mosque", http://www.hvac-turkey.com/detail-41-themagnificent-suleymaniye-mosque, accessed February 26, 2014.

Vitruvius, De Architetctura Libri X; Book II, Chapter I. English translation according to http:// www.vitruvius.be/boek2h1.htm, accessed January 15, 2014.

Gottfried Semper, Die vier Elemente der Baukunst (Braunschweig: Friedrich Vieweg und Sohn, 1851), p. 55.

Mies van der Rohe, in the manuscript for a lecture dated June 19th 1924: "While we want to stand with both feet firmly on the ground, we want to reach with our head to the clouds", in The Artless World: Mies van der Rohe on the Building Art, Fritz Neumeyer,trans. Mark Jarzombek (Cambridge Mass.: MIT Press, 1991), pp. 249-250. 
Allen, Stan. "Field Conditions." In Stan Allen Architects: Points + Lines, 92-102. Princeton: Princeton Architectural Press, 1999.

Allen, Stan and Marc McQuade eds.. Landform Building. Baden: Lars Müller, 2011.

Asad, Muhamad. The Message of the Quran (1980). Gibraltar: Dar Al Andalus, www.usc. edu/schools/college/crcc/private/cmje/religious text/ The Message of The_Quran by Muhammad Asad.pdf.

Bible, King James Version, Cambridge edition, http://www.kingjamesbibleonline.org.

Burke, Edmund. A Philosophical Inquiry into the Origin of Our Ideas of the Sublime and the Beautiful (1756). The Project Gutenberg EBook \#15043, released March 27, 2005.

Dobrović, Nikola. “Osvrt na temu ambijent.” Arhitektura (Zagreb), 90 (1965):7 .

Van Doesburg, Theo. On European Architecture 1924- 1931. Basel: Birkhäuser Verlag, 1990. Freely, John. A History of Ottoman Architecture. Boston: WIT Press, 2011.

Giedion, Sigfried. “Jørn Utzon and the Third Generation.” Zodiac (Milano) 14 (1965): 36- 47.

Günay, Reha. A Guide to the Works of Sinan the Architect in Istanbul. Istanbul: Yem Yayin, 2006. Kahera, Akel, Latif Abdulmalik and Craig Anz. Design Criteria for Mosques and Islamic Centres. London: Elsevier Architectural Press, 2009.

Kant, Immanuel. Critique of Judgement; Part I: Critique of Aesthetic Judgement (1790), trans. James Creed Meredit. eBooks@Adelaide, University of Adelaide, 2005, http://ebooks. adelaide.edu.au/k/kant/immanuel/k16j/index.html.

Le Corbusier. Journey to the East (1911), trans. Ivan Žaknić. Cambridge Mass.: MIT Press, 2007.

Maqsood, Ruqaiyyah Waris. Islam. London: Hodder \& Stoughton Educational, 2003.

Mondrian, Piet. "Plastic Art and Pure Plastic Art" (1937), in Ross, Stephen David (ed.). Art and its Significance. New York: State University, 1999.

Neumeyer, Fritz. The Artless World: Mies van der Rohe on the Building Art, trans. Mark Jarzombek. Cambridge Mass.: MIT Press, 1991.

Porter, Venetia, ed. Hajj, Journey to the Heart of Islam (exhibition catalogue). London: The British Museum Press, 2012.

Radović, Goran, ed. Places for Re-encouters: Recycling the Space (exhibition catalogue). La Biennale di Venezia, 12. Mostra Internazionale di Architettura, partecipazioni nazionali: Montenegro, 2010.

Radović, Ranko. Antologija kuća. Belgrade: Građevinska knjiga, 1989.

Semper, Gottfried. Die vier Elemente der Baukunst. Braunschweig: Friedrich Vieweg und Sohn, 1851.

Strajnić, Kosta. Dubrovnik bez maske: uzaludni napori i teška razočaranja. Dubrovnik: writer’s edition, 1930.

."Savremena arhitektura Jugoslovena: Nikola Dobrović i njegovo značenje." Arhitektura (Ljubljana) 4 (1932): 108-118.

Utzon, Jørn. "Platforms and Plateaus.” Zodiac (Milano) 10 (1963):110-115.

Vitruvius. De Architetctura Libri X; Book II, Chapter I, English translation. http://www. vitruvius.be/boek2h1.htm.

Watson, Anne, ed. Building a Masterpiece: the Sydney Opera House. Sydney: Powerhouse, 2006. 


\section{ARHITEKTURA UTOPIJA REALIZAM: TEMATSKI OKVIR Ljiljana Blagojević}

Termin ili koncept realizma re-aktuelizovan je u skorašnjim teorijskim debatama od rasprava u filozifiji i estetici do onih u teoriji i praksi arhitekture. Počev od 2000. godine, arhitektonski diskurs se često bavi širokim spektrom srodnih pitanja koja proističu iz post-kritičkih rasprava o utopijanizmu i realizmu i mogućnosti jednog "utopijskog realizma", kako je to sugerirao Rajnhold Martin (2005). Rasprave o realizmu ponovo rezoniraju u arhitektonskoj teoriji kao odraz Manifesta novog realizma, filozofa Mauricija Ferarisa iz 2011 godine. Pitanja realizma naspram postmodernizma, "novog realizma" koji nastaje na pepelu post-modernizma, kritički i operativni pojmovi realizma i slično, postavljana su kako kroz prakse savremene arhitekture tako i kroz preispitivanje realizma i socijalističkog realizma u istoriji i teoriji arhitekture. Postavka tematskog okvira u ovom članku SAJ: Arhitektura Utopija Realizam ima za cilj da produbi tekuće rasprave o odnosima arhitekture sa realizmom i utopijom.

KLJUČNE REČI: ARHITEKTURA, UTOPIJA, REALIZAM, AUR MEĐUNARODNA NAUČNA KONFERENCIJA, UNIVERZITET U BEOGRADU - ARHITEKTONSKI FAKULTET

\section{UTOPIJA STVARNOSTI. REALIZMI U ARHITEKTURI IZMEĐU IDEOLOGIJE I FENOMENOLOGIJE Silvia Malcovati}

Predložen povodom Prvog Kongresa sovjetskih pisaca u Moskvi 1934 godine, pojam realizma u teorijskim raspravama o arhitekturi u ranim tridestim godinama dvadesetog veka, izgleda kao dvosmisleni pojam, koji se koleba između idealizma i ideologije, inovativnog istraživanja i istoricističkog formalizma. Neuspeh socijalističkog realizma i kriza njegove naglašene i monumenalističke arhitektonske slike, jasno pokazuju utopijski karakter realističkog "sna", ali isto tako, na neki način, njegovu maštovitu moć nastojanja da se izgradi bolji svet.

Pitanje realizma aktuelno je i posle Drugog svetskog rata. Posebno u Italiji realizmi se pretvaraju u alternative savremenoj paradigmi, ni manje ni više utopijski, već otvoreni prema novim postmodernističkim američkim idejama, kao i arhitekturi grupe "Tendenza".

U ovom radu predloženo je pregledno istraživanje realizama dvadesetog veka kao instrumenta koji odražava stanje u arhitekturi: nakon ekscesa postmodernog populizma, razočarenja "Architettura Razionale" i dijalektike rekonstrukcije - dekonstrukcije, izgleda da se ponovo pojavljuje u arhitekturi jedan novi bauk "Realizma" kao način reagovanja na trenutno arhitektonsko i urbano stanje.

KLJUČNE REČI: UTOPIJA, REALIZAM, ITALIJANSKA ARHITEKTURA POSLERATNOG PERIODA, “TENDENZA”, POSTMODERNIZAM, NOVI REALIZAM, ARHITEKTURA GRADA

\section{(SOC)REALIZMI U PRAKSI: PONOVNO ČITANJE SOVJETSKOG ISKUSTVA IZ TRIDESTIH GODINA PROŠLOG VEKA \\ Alessandro De Magistris}

Diskurs o realizmu u savremenoj arhitektonskoj raspravi izgleda da zaobilazi složenost istorijskih korena ove pojave u arhitekturi dvadesetog veka i, posebno, diskurs o socijalsitičkom realizmu: izvor mnogih perspektiva koje gravitiraju oko ideje realizma u posleratnom periodu i koje predstavljaju značajan momenat u teorijskoj raspravi i projektantskoj praksi između tridesetih i pedestih, sve do Staljinove smrti.

Cilj ovog članka je da predloži jedno artikulisano razmišljanje o iskustvu socrealizma, istraženog u njegovim "formativnim" godinama, u ključnoj fazi njegove razrade. Daleko od toga da je rezultat krutog, teoretskog određenja od vrha nadole, realizam je definisan na pragmatičan način, u većini radova projektanske prakse i teorije. Eklekticizam i pluralizam njegovih izražaja, koji gravitiraju oko ideje kritičke asimilacije istorije, objašnjava razvoj socrealizma između ratnog i posleratnog perioda u SSSR i istočno evropskim zemljama i nalazi svoj najjasniji iskaz u moskovskom metrou. 


\section{MANFREDO TAFURI I KRITIKA REALIZMA}

\section{Luka Skansi}

Jedna od glavnih tema istorijskog rada Manfreda Tafurija, bilo da je analizirao arhitekturu renesanse, iluminizma ili dvadesetog veka, ticala se odnosa između arhitektonskog stvaralaštva i stvarnosti. Ova tema takođe je premisa, odnosno uvodni teorijski okvir, za njegov istorijski i kritički diskurs "kritike realizma", koji je opisan u eseju Architettura e Realismo (Arhitektura i realizam), objavljenom 1985. godine. Ovaj esej predstavlja zaključne Tafurijeve opservacije italijanske posleratne arhitektonske kulture. Neorealizam postaje u njegovom eseju predmet prilično jedinstvene istorijske kontekstualizacije, predmet duboke kritike i, konačno, demistifikacije.

KLJUČNE REČI: ARHITEKTURA, REALIZAM, NEOREALIZAM, KRITIKA, POSLERATNA ITALIJA

\section{FRENK LOJD RAJT, EJN REND I HIPER-KAPITALISTIČKA UTOPIJA}

\section{Tijana Vujošević}

Ovaj rad predstavlja paralelno čitanje Frenk Lojd Rajtovog traktata Iščezavajući grad i Ejn Rendovog romana The Fountainhead. Autorka istražuje retoriku anti-urbanih utopija iz ere Depresije isnspirisanu mitom američkih pionira i osvajanjem granice. Ona identifikuje tri karakteristike Rajtovih i Rendovih anti-urbanih konstrukta: slavljenje muževnosti, poricanje političkog angažmana i anti-intelektualizam, sve to kombinovano u snu prvobitnog, idealnog kapitalizma. Koje su protivrečnosti i nedoslednosti svojstvene u građenju anti-urbane utopije? Ovo je pitanje na koje ovaj rad namerava da odgovori.

KLJUČNE REČI: MODERNIZAM, UTOPIJSKA FIKCIJA, ANTI-URBANIZAM, USONIA, THE FOUNTAINHEAD -

FAUNTEJNHED, IDEOLOGIJA, MUŠKOST, ANTI-INTELEKTUALIZAM

\section{MESTO [PROSTOR] NE-MESTO \\ Krunoslav Ivanišin}

Čak iako se nikada ne materijalizuju kao zgrade, arhitektonski projekti pripadaju stvarnom svetu. Odvojeno od stvarnog prisustva, ali bez lišavanja merljivih prostornih osobina, ovi skupovi tehničkih crteža u srazmeri, opisa i proračuna objašnjavaju buduću fizičku relanost u pogledu prostora, materijalnosti i forme, sa ciljem stvaranja sveta bar malo boljeg nego što je onaj iz koga potiču. Topografski izazovno, divno mesto pored mora; neko specifično gusto urbano okruženje; intrigantan način razmišljanja : neposredni kontekst prethodi i prati stvarnu izgradnju arhitektonskog dela. To je očigledna činjenica sama po sebi koju istoricističke konceptualizacije i klasifikacije ne mogu da poreknu. UTOPIJSKI ili REALISTIČNI, arhitektonski projekti su po svojoj prirodi vezani za mesta. Samo mera njihovog mešanja i uplitanja sa tim mestima može da varira. U našem post-globalizovanom svetu, i utopijski i realistični kvaliteti se mogu naći u projektima koji su hiperrealistični prema neposrednom kontekstu i koji se kontekstima bave minimalno, samo u pogledu raspoređivanja opterećenja, prilagođavanja stvarnoj topografiji, ili klimatskoj zaštiti.

KLJUČNE REČI: MESTO, ARHITEKTA, PROJEKAT, MATERIJAL, [PROSTOR], KONTEKTS, ARHITEKTURA, NE- MESTO 